ISSN1027-5495. Functional Materials, 23, No.3 (2016), p. 457-462

doi:http://dx.doi.org/10.15407/fm23.03.457

(C) 2016 - STC “Institute for Single Crystals"

\title{
Use of time series models to forecast the evolution of corrosion pit in steel rebars
}

\author{
$X u$ Yidong \\ School of Civil Engineering and Architecture, Ningbo Institute of \\ Technology of Zhejiang University, Ningbo, Zhejiang, 315100, P.R. China
}

Received May 15,2016

\begin{abstract}
This paper presents the time series method to forecast the evolution of pitting depth in corroded reinforcing steel bars. Basic time series analysis models are introduced, and the method for establishing the autoregressive integrated moving average (ARIMA) model is described through an example. Based on ARIMA model, the pitting depth in reinforcing steel bars under two different corrosion environments is predicted. The results show that ARIMA model can describe the variation tendency of pitting depth in corroded reinforcing steel bars quantitatively. The predicted values and the observed ones are in good conformity.

Keywords: time series analysis, autoregressive integrated moving average model, pitting evolution, steel rebars.

Представлен метод временных рядов для прогнозирования развития повреждений в проржавевших армирующих стальных стержнях. Определены базовые модели анализа временных рядов. Метод для установления авторегрессии интегрированный скользящей средней модели (ARIMA) описывается на примере. На основе модели ARIMA, прогнозируется глубина точечной коррозии в армирующих стальных стержнях в двух различных средах. Результаты показывают, что ARIMA модель может описать качественно и количественно различные тенденции глубины повреждений в проржавевших армирующих стальных стержнях. Прогнозируемые значения и наблюдаемые находятся в хорошем соответствии.
\end{abstract}

Використання моделей тимчасових рядів для прогнозування еволюції корозією в сталевих арматурних прутках. Сюй Iдон

$\mathrm{У}$ роботі представлений метод часових рядів для прогнозування розвитку глибини іржавіння в кородованих армуючих сталевих стрижнях. Представлені основні моделі аналізу часових рядів і описаний на прикладі метод створення моделі авторегресивного інтегрованого рухомого середнього (ARIMA). На основі моделі ARIMA передбачена глибина іржавіння в армуючих сталевих стрижнях в двох різних кородуючих середовищах. Результати показують, що модель ARIMA може кількісно описувати тенденції зміни глибини іржавіння в кородованих армуючих сталевих стрижнях. Передбачені значення знаходяться в хорошій згоді із тими, що спостерігалися.

\section{Introduction}

Structure deterioration induced by corrosion of reinforcing bars is one of the major problems in reinforced concrete structures. How to forecast the pitting depth of corroded reinforcing bars are problems of current research. Owing to the discreteness and transient behavior of steel corrosion, it is difficult to track the complete process of pitting depth evolution.
The quantitative evaluation of pitting depth evolution mainly depends on the actual measurement of pitting depth at different position, which belongs to post-operation analysis. Present studies indicate that lots of factors, such as environment, stress state and service time, can influence the characteristics of steel corrosion $[1,2]$. It is difficult to establish an effective theoretical model for pitting depth evolution. 
A time series is a set of sequential data points, measured typically at successive points in time or space at uniform intervals. Time series analysis comprises methods for analyzing time series data in order to extract meaningful statistics and other characteristics of the data, which can be used to describe, explain, predict, and control changes through time of selected variables [3]. This method has already been applied in structural health monitoring widely [4-7]. Kim applies time series analysis to investigate whether the groundwater quality in the coastal area is affected by the tide [8]. Erdopan also applies time series analysis to describe the dynamic movements of suspension bridges [9].

The surface profile of corroded reinforcing bar is a random sequence in spatial order. The fluctuation of pitting depth is a function of depth, instead of a function of time. The long wavelength of roughness corresponds to low frequency component in time domain, and vice versa.

Based on time series analysis, this paper is aimed to develop a new approach to forecasting the pitting depth evolution in reinforcing steel bars. By extracting the abundant information embedded in local pitting depth, the evolution law of corroded surface profile can be predicted. The results of this analysis will become the basis for corrosion damage evolution of corroded reinforcing steel bars.

\section{Experimental}

A commercial hot rolled plain steel bar type HPB235 (with nominal diameter of $12 \mathrm{~mm}$ ) according to ISO Standards 6935-1 was used. The specimen used for the accelerated wet-dry cycle corrosion test was about $400 \mathrm{~mm}$. The two end parts of the specimen (each is about $125 \mathrm{~mm}$ ) were coated with anticorrosive grease and plastic film. The middle part of the specimen (about $150 \mathrm{~mm}$ ) was designed as the corrosion region, as is shown in Figure 1. The salt solution was prepared by dissolving 5 parts by mass of sodium chloride $(\mathrm{NaCl})$ into 95 parts of distilled water. The simulated concrete pore solution was made up of $0.6 \mathrm{M}$ potassium hydroxide $(\mathrm{KOH})$ $+0.2 \mathrm{M}$ sodium hydroxide $(\mathrm{NaOH})+0.001 \mathrm{M}$ calcium hydroxide $\left(\mathrm{Ca}(\mathrm{OH})_{2}\right)$. The derusting solution was prepared by mixing $3 \%$ hexamethylene tetramine (analytical reagent) into 97 parts diluted hydrochloric acid [10].

To determine the corrosion characteristics of reinforcing bar in chloride-free and chloridecontaminated simulated concrete solutions, four specimens were subjected to wet-dry cycle corrosion test. Two specimens (denoted as SC) were regularly sprayed using the salt solution and the other two specimens (denoted as SK)

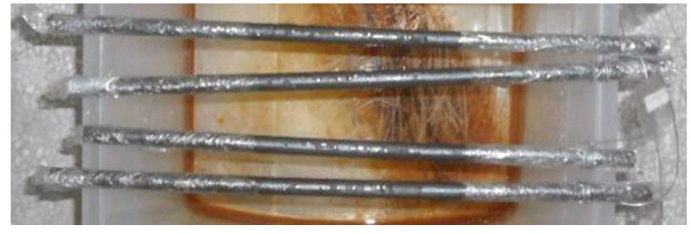

Fig. 1. Specimens of accelerated wet-dry cycle corrosion test.

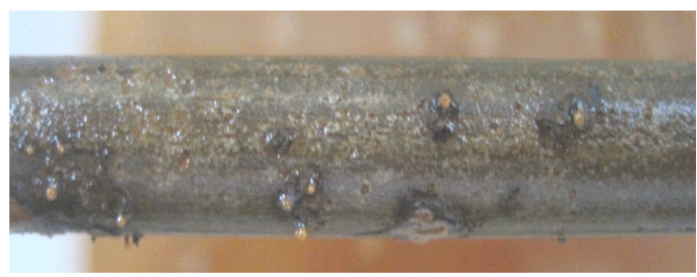

a) Before de-rusting

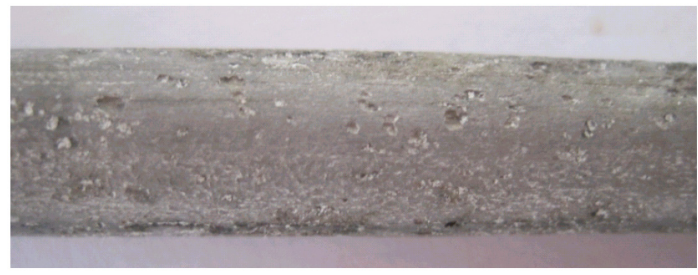

b) After de-rusting

Fig. 2. Reinforcing bar specimen before and after de-rusting.

were regularly sprayed using the mixture of salt solution and simulated concrete pore solution every 24 hours. When the test was completed, the specimens were washed using the derusting solution to remove corrosion products, as is shown is Figure 2. The corrosion mass loss ratio then was calculated, as is shown in Table 1. Along the length of corroded reinforcing steel bars, the pitting depth were measured by using single cusp dialgauge (with accuracy of $0.01 \mathrm{~mm}$ ) at intervals of $2.5 \mathrm{~mm}$ length [11].

\section{Basic theory of time series analysis}

\subsection{Classification of time series model}

Let $\left\{X_{t}\right\}$ be stationary series with zero mean and $\left\{a_{t}\right\}$ be white noise, $E\left(a_{s} X_{t}\right)=0(s>t)$, which can satisfy Eq. (1),

$$
\begin{aligned}
& X_{t}-\varphi_{1} X_{t-1}-\varphi_{2} X_{t-2}-\ldots-\varphi_{p} X_{t-p} \\
& =a_{t}-\theta_{1} a_{t-1}-\theta_{2} a_{t-2}-\ldots-\theta_{q} a_{t-q}
\end{aligned}
$$

Table 1. Test parameters of reinforcing bar specimens under chloride attacks

\begin{tabular}{|c|c|c|c|}
\hline Code & $\begin{array}{c}\text { corrosion mass } \\
\text { loss ratio [\%] }\end{array}$ & Code & $\begin{array}{c}\text { corrosion mass } \\
\text { loss ratio [\%] }\end{array}$ \\
\hline SC-P1 & 1.25 & SK-P1 & 0.92 \\
\hline SC-P2 & 2.82 & SK-P2 & 1.99 \\
\hline
\end{tabular}


Xu Yidong / Use of time series models to forecast the evolution ...

Table 2. Autocorrelation and partial autocorrelation coefficient of different models

\begin{tabular}{|c|c|c|c|}
\hline Model & $A R(p)$ & $M A(q)$ & $A R M A(p, q)$ \\
\hline Autocorrelation coefficient & tail & truncation of order $q$ & tail \\
\hline Partial correlation coefficient & truncation of order $p$ & tail & tail \\
\hline
\end{tabular}

where $\varphi_{1}, \varphi_{2}, \ldots, \varphi_{p}$ is autoregressive coefficient and $\theta_{1}, \theta_{2}, \ldots, \theta_{q}$ is moving average coefficient. Then $\left\{X_{t}\right\}$ is referred to as $\operatorname{ARMA}(p, q)$, which means autoregressive moving average model. $p, q$ are the orders of the model.

By introducing postpone operator $B$,

$$
\begin{aligned}
& B^{k} X_{t}=X_{t-k}(k \text { is positive integer }) \\
& B^{k} a_{t}=a_{t-k} \\
& B^{k} c=c(c \text { is constant })
\end{aligned}
$$

and let

$$
\begin{aligned}
& \varphi(B)=1-\varphi_{1} B^{1}-\varphi_{2} B^{2}-\ldots-\varphi_{p} B^{p} \\
& \theta(B)=1-\theta_{1} B^{1}-\theta_{2} B^{2}-\ldots-\theta_{q} B^{q}
\end{aligned}
$$
(4).

Then $A R M A(p, q)$ can be expressed as Eq.

$$
\varphi(B) X_{t}=\theta(B) a_{t}
$$

When $q=0$, then $\operatorname{ARMA}(p, 0)$ can be transformed into Eq. (5), denoted as $A R(p)$.

$$
X_{t}=\varphi_{1} X_{t-1}+\varphi_{2} X_{t-2}+\ldots+\varphi_{p} X_{t-p}+a_{t}
$$

When $p=0$, then $\operatorname{ARMA}(0, q)$ can be transformed into Eq. (6), denoted as $M A(q)$.

$$
X_{t}=a_{t}-\theta_{1} a_{t-1}-\theta_{2} a_{t-2}-\ldots-\theta_{q} a_{t-q}
$$

In many practical fields, the observed data sequence is nonstationary series, which needs smooth processing. Then difference operator $\nabla$ can be defined as follow,

$$
\nabla X_{t}=X_{t}-X_{t-1}
$$

The relationship between difference operator $\nabla$ and postpone operator $B$ is shown in Eq. (8)

$$
\nabla^{d}=(1-B)^{d}
$$

By using difference transformation of order $\mathrm{d}\left(\nabla^{d} X_{t}\right)$, nonstationary series $\left\{X_{t}\right\}$ can be transformed into stationary series. Then Eq. (9) can be derived from Eq. (4),

$$
\varphi(B)(1-B)^{d} X_{t}=\theta(B) a_{t}
$$

Eq. (9) is referred to as $\operatorname{ARIMA}(p, d, q)$ which means autoregressive integrated moving average model [12, 13].

\subsection{The establishment of $\operatorname{ARIMA}(p, d, q)$}

The ARIMA model takes three steps to establish: model recognition, model estimation and model checking.

The key in pattern recognition is to determine the order of autoregression $(p)$, difference $(d)$ and moving average $(q)$. Parameter $d$ can be estimated by scatter chart. If no tendency occurred, it shows that the time series is a stationary sequence and parameter $d=0$. Otherwise, the nonstationary sequence should be transformed into stationary sequence by using difference transformation, and parameter $d$ equals to the difference order. Parameter $p$ and $q$ can be initially estimated by the tail and truncation properties of autocorrelation coefficient and partial correlation coefficient, as is shown in Table 2. Besides, BIC criterion is also suitable for order estimation. Practices show that smaller statistical magnitude is better.

Model estimation is based on mass observed data and model parameter can be estimated from these sample data. The most frequently used parameter estimation methods include related moment estimation, least square estimation and maximum likelihood estimation.

After the model recognition and estimation, the time series forecasting model can be established preliminary. Whether the model is correct or not mainly depends on model checking by correlation function test. If the time series forecasting model is correct, the residual sequence generated by estimated and the observed value should be white noise sequence $[14,15]$.

\subsection{The application of time series analysis to forecast the pitting depth in reinforcing bars}

By using statistical software SPSS and test data, the $\operatorname{ARIMA}(p, d, q)$ modelling process of is discussed in detail. The pitting depth sequence is plotted according to the observed data covered the $100 \mathrm{~mm}$ corrosion length of the specimen. As is shown in Figure 3(a), the mean value of this sequence is significantly different from zero, which indicates that the pitting depth sequence is a nonstationary series. By first order difference transformation, a stationary series can be obtained, as is shown in Figure 3(b). Therefore, parameter $d$ is initially estimated as 1. 

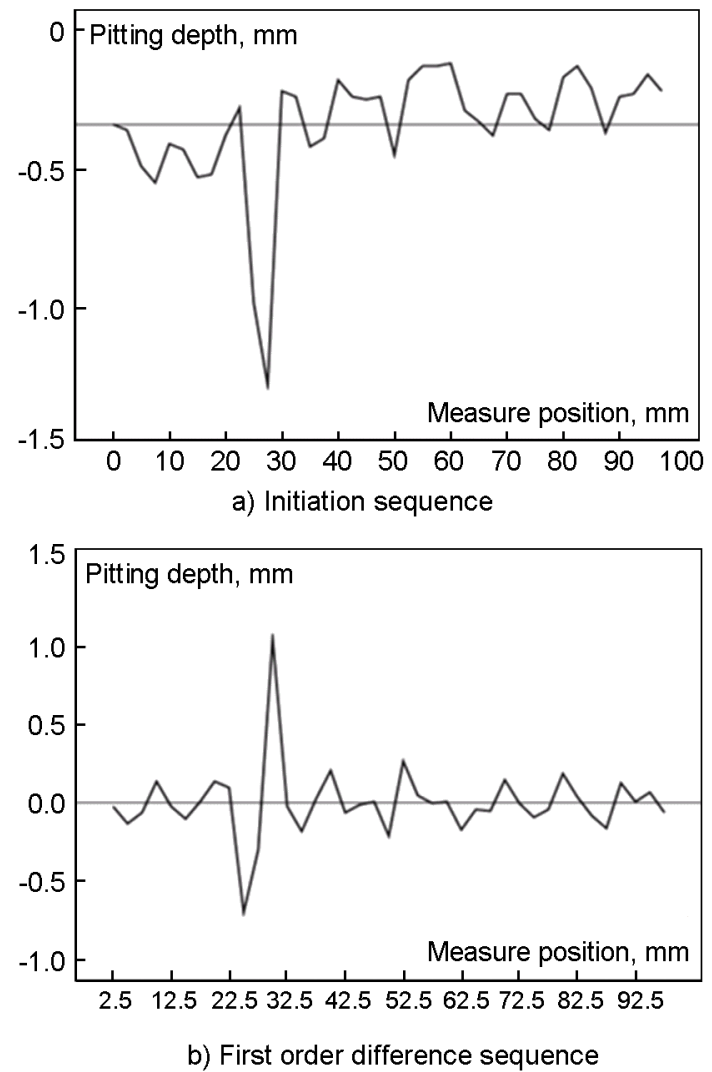

Fig. 3. Before and after difference sequence.

Figure 4 plots the autocorrelation function (ACF) and partial autocorrelation function (PACF) diagrams of first order difference sequence. The value of delay order is $[n / 4]$ where $n$ is the number of sample and [] means rounding operation. As is shown in Figure 4, the $\mathrm{ACF}$ and PACF of difference sequence present damped sine waveform, which can be seemed as tail or second order truncation. According to the criterion presented in Table 2, two time series forecasting models, $\operatorname{ARIMA}(2,1,0)$ and $A R I M A(2,1,2)$, are initially recognized.

The model parameters of $A R I M A(2,1,0)$ and $A R I M A(2,1,2)$ are calculated by SPSS, as is demonstrated in Table 3. In comparison, BIC statistical magnitude of $\operatorname{ARIMA(2,1,0)}$ is smaller than that of $\operatorname{ARIMA}(2,1,2)$. Therefore, is more suitable for this case.

Figure 5 shows the white noise testing of residual sequence of $\operatorname{ARIMA}(2,1,0)$. The autocorrelation coefficients of residual sequence are all located in stochastic intervals, which

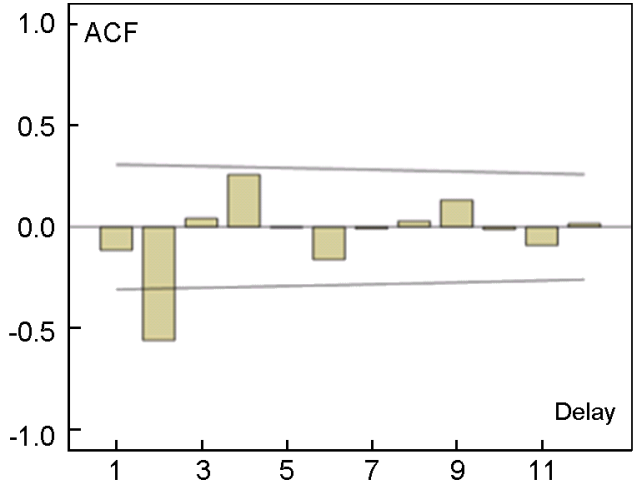

a) $\mathrm{ACF}$

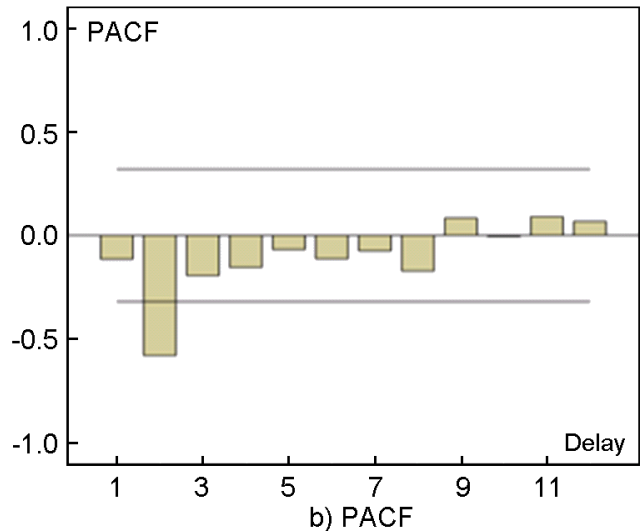

Fig. 4. Autocorrelation and Partial autocorrelation diagram.

indicate that there exists no significant difference with zero. The residual sequence is a white noise sequence and the model can pass the check.

The mathematical model can be expressed as Eq. (10).

$$
\left(1-\varphi_{1} B^{1}-\varphi_{2} B^{2}\right)(1-B) X_{t}=a_{t}+c
$$

By substituting the parameters shown in Table 3 into Eq. (10), the time series forecasting model of observed pitting depth can be expressed as Eq. (11). In order to verify the rationality of time series forecasting model, the observed pitting depth covered the $100 \mathrm{~mm}$ $120 \mathrm{~mm}$ corrosion length of the specimen is predicted by $A R I M A(2,1,0)$ and $\operatorname{ARIMA}(2,1,2)$. As is shown in Figure 6 and Figure 7, the predicted results of $A R I M A(2,1,0)$ is more precise than that of $\operatorname{ARIMA}(2,1,2)$.

Table 3. Parameters of ARIMA model

\begin{tabular}{|c|c|c|c|c|c|c|}
\hline Parameter & $\begin{array}{c}A R(1) \\
\left(\varphi_{1}\right)\end{array}$ & $\begin{array}{c}A R(2) \\
\left(\varphi_{2}\right)\end{array}$ & $\begin{array}{c}M A(1) \\
\left(\theta_{1}\right)\end{array}$ & $\begin{array}{c}M A(2) \\
\left(\theta_{2}\right)\end{array}$ & $\begin{array}{c}\text { Const } \\
(c)\end{array}$ & BIC \\
\hline ARIMA $(2,1,0)$ & -0.179 & -0.561 & --- & --- & 0.005 & -2.965 \\
\hline ARIMA $(2,1,2)$ & -0.032 & -0.230 & 0.459 & 0.536 & 0.009 & -2.854 \\
\hline
\end{tabular}




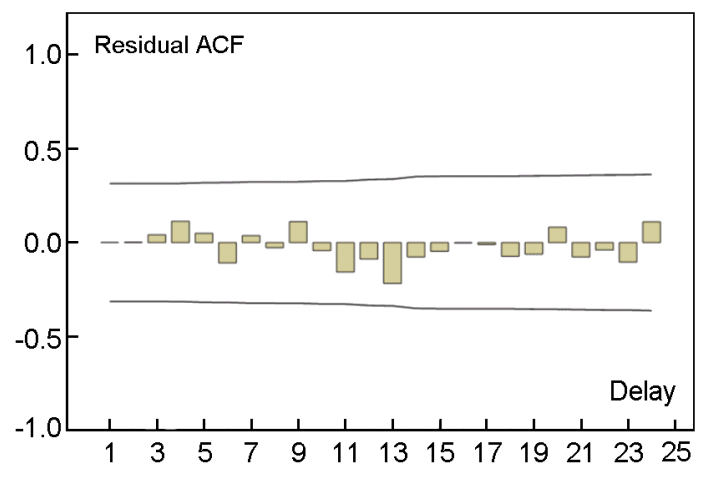

Fig. 5. Residual autocorrelation function diagram of $A R I M A(2,1,0)$ model.

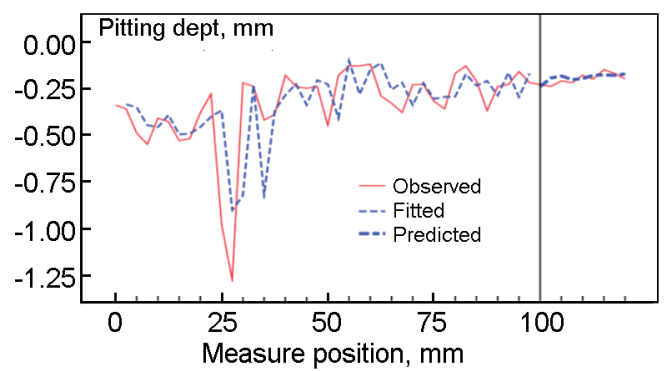

Fig. 6. Prediction of $\operatorname{ARIMA}(2,1,0)$ model.

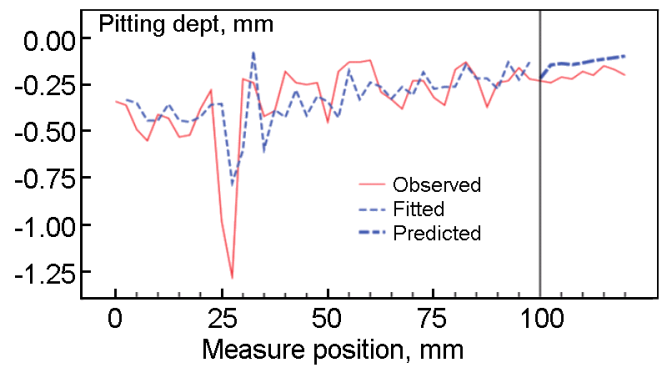

Fig. 7. Prediction of $A R I M A(2,1,2)$ model.

$$
\begin{aligned}
X_{t}= & 0.821 X_{t-1}-0.382 X_{t-2}+ \\
& +0.561 X_{t-3}+a_{t}+0.005
\end{aligned}
$$

By using the modeling method mentioned above, the time series forecasting models of four specimens are established. As is demonstrated in Figure 8, the model predictions agree very well with experimental measurements.

\section{Conclusions}

Hot rolled plain steel bars were corroded by accelerated wet-dry cycle corrosion test, and the pitting depth of corroded steel bars was measured by using single cusp dialgauge. By introducing time series analysis into the research field of reinforced concrete, the modeling method of time series analysis has been elaborated. The autoregressive integrated moving average model $\operatorname{ARIMA}(p, d, q)$ has been established to forecast the pitting depth of reinforcing bars.

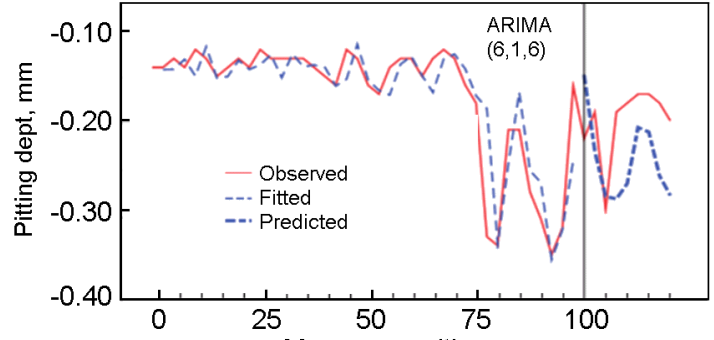

a) SC-P1 Measure position, $\mathrm{mm}$

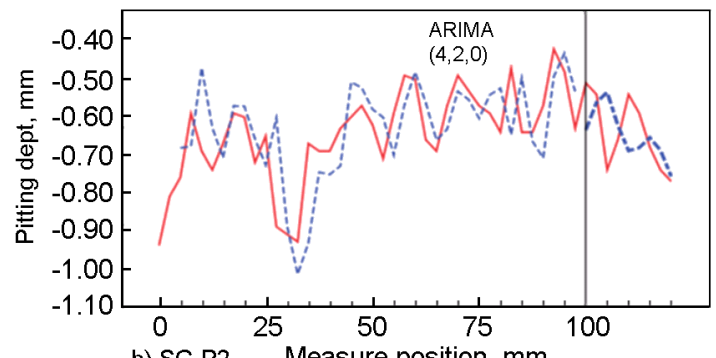

b) SC-P2 Measure position, $\mathrm{mm}$
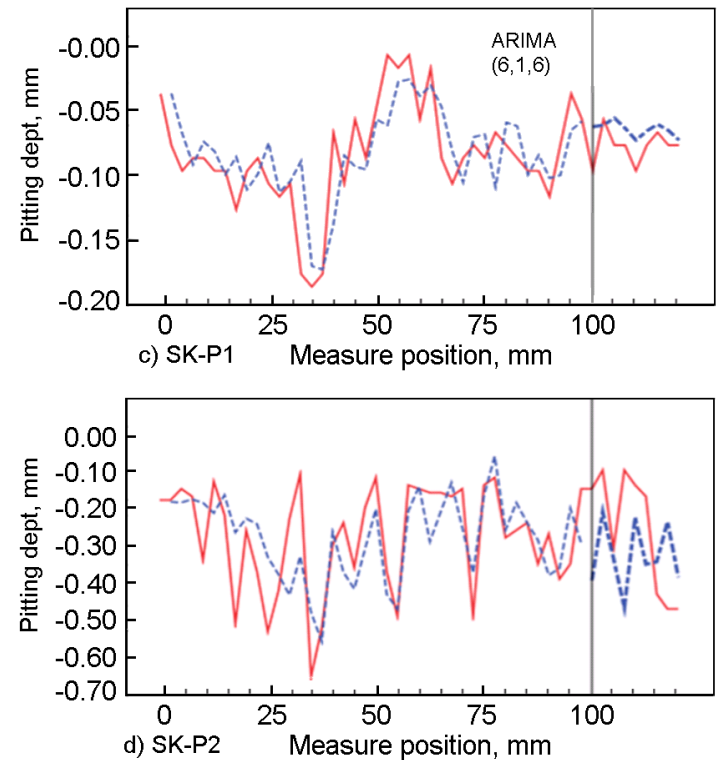

Fig. 8. Time series prediction of pitting depth.

The model predictions agree very well with experimental measurements.

\section{Acknowledgements}

The authors wish to acknowledge the financial support of "Zhejiang Provincial Natural Science Foundation (grant no. LY15E080025)", "National Natural Science Foundation of China" (grant no. 51008276), "Ningbo Scientific \& Technological Innovation Team" (grant no. 2011B81005) and China Scholarship Council (grant no. 201308330417). 


\section{References}

1. Y. Xu and C. Qian, J. Wuhan, Univ. Techn. Mater. Scie., 28, 538, 2013.

2. Y. Xu, C. Qian and J. Sun, J. Southeast Univ., 42, 492, 2012.

3. G. Robinson, Time Series Analysis, in: R K, NIGEL T (Eds.), Oxford: International Encyclopedia of Human Geography, Elsevier, 2009.

4. C. Peter, J. Brownjohn, Mech. Syst. Signal Process., 22, 295, 2008.

5. R. Oliver, P. Omenzetter, Mech. Syst. Signal Process., 24, 1556, 2010.

6. M. Gul, F. Necati, Mech. Syst. Signal Process., 23, 2192, 2009.

7. M. Gul, F. Necati, J. Sound Vib., 330, 1196, 2011.
8. J. Kim, J. Lee, T. Cheong, J. Hydr., 300, 188, 2005.

9. H. Erdopan, E.Gelal, Nonlinear. Anal.: Real World Appl., 10, 910, 2009.

10. Y. Xu, C. Qian, L. Pan, PLoS ONE, 7, e29956, 2012.

11. Y. Xu, C. Qian, Adv. Mater.Res., 163-167, 3118, 2011.

12. C. Yu, SPSS and Statistic Analysis, Beijing: Electronic Industry Press, 2007.

13. C. Liu, Stochastic Process, Wuhan: Huazhong University of Science and Technology Press, 2001.

14. F. Wang, The application of SPSS in social - economic analysis, Hefei: China Science and Technology University Press, 2009.

15. Y. Zhang, N. Peng, H. Xu, China Civil Engin. J., 42, 109, 2009. 